\title{
Families of loblolly pine that are the most stable for resistance to fusiform rust are the least predictable
}

\author{
S.E. McKeand, H.V. Amerson, B. Li, and T.J . Mullin
}

\begin{abstract}
In an extensive series of trials with open-pollinated families of loblolly pine (Pinus taeda L.), resistance to fusiform rust disease (caused by Cronartium quercuum (Berk.) Miyabe ex Shirai f. sp. fusiforme) at individual test sites was relatively unpredictable for the families deemed most resistant. The most resistant families were also the most stable for performance across test sites, with stability defined as the slope of the regression of family means for rust infection versus site means for rust infection. A family's R-50 value (its predicted rust infection level when the site mean infection is 50\%) was correlated to its stability parameter or slope $(r=0.78)$. On average, any one family's level of infection (\% galled) was reasonably predictable for any given infection level at a given site; the average coefficient of determination $\left(r^{2}\right)$ was 0.78 for the regression of family means for rust infection versus site means for rust infection. However, the six most stable families for resistance had the lowest $r^{2}$ values (average $r^{2}=0.58$ ). We speculated that the lower predictability for the most resistant families was due to interactions of specific resistance genes in these families and corresponding avirulence and (or) virulence levels in the pathogen populations that may differ among sites. Although the predictability of the individual resistant families was relatively low, if these families were bulked into a resistant seed lot, they performed in a more predictable manner with $r^{2}=0.74$ for the regression of the bulk mean versus site means. Bulks of four to six highly resistant families appeared to be a good solution to obtain stable and predictable performance across a range of sites.
\end{abstract}

Résumé : Une série d'essais à grande échelle avec des familles de pin à encens (Pinus taeda L.) issues de pollinisation libre ont été réalisés afin d'évaluer la résistance à la rouille fusiforme (Cronartium quercuum (Berk.) Miyabe ex Shirai f. sp. fusiforme). Les résultats dans différents sites expérimentaux montrent que la résistance à la rouille demeure relativement imprévisible pour les familles considérées comme les plus résistantes. Ces dernières étaient aussi celles qui présentaient la performance la plus stable dans tous les sites; la stabilité étant définie comme la pente de la régression entre le taux moyen d'infection dans une famille et le taux moyen d'infection dans un site. La valeur de R-50 d'une famille (taux d'infection calculé lorsque le taux moyen d'infection dans un site est de $50 \%$ ) est corrélée à son paramètre de stabilité ou à sa pente $(r=0,78)$. En moyenne, n'importe quel taux d'infection d'une famille (évalué par le pourcentage de chancres) était dans une certaine mesure prévisible peu importe le taux d'infection pour un site donné; la moyenne des coefficients de régression $\left(r^{2}\right)$ entre le taux moyen d'infection dans une famille et le taux moyen d'infection dans un site était de 0,78 . Cependant, les six familles les plus stables pour la résistance à la rouille avaient les valeurs de $r^{2}$ la plus faible (valeur moyenne de $r^{2}=0,58$ ). Nous croyons que la plus faible prévisibilité dans le cas des familles les plus résistantes était due aux interactions entre des gênes spécifiques de résistance dans ces familles et les niveaux correspondants de virulence et (ou) avirulence dans les populations de l'agent pathogène qui varient sans doute selon le site expérimental. Bien que la prévisibilité ait été relativement faible dans le cas des familles résistantes prises individuellement, leur performance était plus prévisible, avec un coefficient de détermination de 0,74 entre la moyenne du groupe et la moyenne du site, si ces familles étaient regroupées en lots de graines résistants. Des lots combinés de quatre à six familles résistantes semblent une solution intéressante pour obtenir une performance stable et prévisible pour une variété de sites.

[Traduit par la Rédaction]

Received 2 July 2002. Accepted 11 February 2003. Published on the NRC Research Press Web site at http://cjfr.nrc.ca on 17 June 2003.

S.E. McKeand, ${ }^{1}$ H.V. Amerson, B. Li, and T.J. Mullin. Department of Forestry, Box 8002, N.C. State University, Raleigh, NC 27695-8002, U.S.A.

${ }^{1}$ Corresponding author (e-mail: Steve_McKeand@ncsu.edu). 


\section{Introduction}

Genetic variation in expression of host resistance to fusiform rust (caused by Cronartium quercuum (Berk.) Miyabe ex Shirai f. sp. fusiforme) is commonly recognized in both slash (Pinus elliottii var. elliottii Engelm.) and loblolly pine (Pinus taeda L.) (Barber et al. 1957; Jewell and Mallett 1967; Kinloch and Stonecypher 1969; Schmidt et al. 1981; Walkinshaw and Bey 1981; Powers and Kraus 1986; Kuhlman and Powers 1988; Kuhlman 1992; Kuhlman and Matthews 1993). In a recent study of 43 open-pollinated families of loblolly pine across 28 diverse test sites in the southeastern United States (McKeand et al. 1999), we reported large family differences for rust infection (\% galled individuals). Predicted rust levels for families at sites where $50 \%$ rust infection are expected (i.e., R-50 values) varied between 22 and $75 \%$. Although family by environment $(\mathrm{G} \times \mathrm{E})$ interaction was statistically significant, its overall variance was small compared with the family variance. Much of the $\mathrm{G} \times \mathrm{E}$ interaction was due to heterogeneous regressions of families across different sites and not family-rank change. One interesting finding was that for some families, the regression of family means for rust infection versus site means for rust infection had low coefficients of determination $\left(r^{2}\right)$ (i.e., the confidence intervals of R-50 values for some families were wide). We speculated that the unpredictable nature of these families may be due to interactions of the family's susceptibility and (or) resistance and specific pathogen avirulence and (or) virulence among sites.

Upon closer inspection of the relationship between the predictability of resistance and stability of resistance, it appeared that the most resistant families typically were also the ones that were least predictable across sites for resistance. Since fusiform rust disease is the most economically important disease of loblolly and slash pine in the southern United States (Anderson et al. 1986; Kinloch and Stonecypher 1969; Kinloch and Walkinshaw 1991; Kuhlman 1992; Powers et al. 1981), we wanted to examine how to best deploy rust-resistant families. In this paper, we conducted additional analyses of the $\mathrm{G} \times \mathrm{E}$ interaction in the trials reported earlier (McKeand et al. 1999).

\section{Materials and methods}

Details of the experimental design and measurements are given by $\mathrm{Li}$ and McKeand (1989) and McKeand et al. (1999). Briefly, open-pollinated families from diverse origins were established in a series of randomized, completeblock design tests, each with six replications of 10-tree row plots of 30-50 families and unimproved check lots. Test trees were evaluated at age 8 years for presence or absence of galls on stems and (or) branches, the standard parameter used to assess rust resistance in loblolly pine. There were 43 open-pollinated families established in 28 test locations in the Coastal Plain from southeast Louisiana to eastern North Carolina (Table 1). Each of the 43 families analyzed was planted on at least six test sites.

The analysis of variance and heritability estimates are given in McKeand et al. (1999) and are not discussed here. The stability of families across sites was assessed using the traditional methods of Finlay and Wilkinson (1963) and Eberhart and Russell (1966). Rust infection across the tests
Table 1. Location and site means at age 8 years for the 28 tests used for the rust stability analyses.

\begin{tabular}{lllll}
\hline Test location & $\begin{array}{l}\text { Height } \\
(\mathrm{m})\end{array}$ & \% rust & \% survival \\
Test & (County, State) & 9.0 & 33 & 92 \\
A & Effingham, Ga. & 5.8 & 49 & 86 \\
8 & East Feliciana, La. & 9.1 & 74 & 82 \\
B & Washington, Ga. & 5.7 & 20 & 86 \\
9 & Columbus, N.C. & 6.0 & 49 & 77 \\
C & Nassau, Fla. & 5.3 & 49 & 82 \\
D & Ware, Ga. & 6.5 & 20 & 88 \\
E & Nassau, Fla. & 9.1 & 62 & 84 \\
F & Camden, Ga. & 7.4 & 63 & 61 \\
G & McIntosh, Ga. & 7.0 & 47 & 92 \\
H & Baldwin, Ala. & 7.2 & 32 & 85 \\
I & Choctaw, Ala. & 6.0 & 26 & 70 \\
J & Bibb, Ala. & 7.3 & 34 & 85 \\
K & Jones, Miss. & 7.1 & 41 & 93 \\
L & Covington, Ala. & 5.5 & 61 & 75 \\
M & Chattahoochee, Ga. & 8.4 & 25 & 85 \\
N & Escambia, Fla. & 8.4 \\
O & Escambia, Fla. & 6.6 & 59 & 80 \\
P & Dallas, Ala. & 9.1 & 36 & 91 \\
Q & Dallas, Ala. & 7.9 & 31 & 82 \\
R & Tuscaloosa, Ala. & 7.1 & 17 & 89 \\
S & Kemper, Miss. & 8.8 & 50 & 85 \\
T & Green, Ala. & 7.1 & 49 & 88 \\
U & Shelby, Ala. & 7.0 & 17 & 93 \\
V & Onslow, N.C. & 6.0 & 25 & 84 \\
W & Pitt, N.C. & 7.6 & 29 & 86 \\
X & Pitt, N.C. & 8.3 & 28 & 76 \\
Y & Georgetown, S.C. & 8.1 & 20 & 77 \\
Z & Fairfield, S.C. & 6.8 & 19 & 86 \\
\hline & & & & \\
\hline
\end{tabular}

averaged $39 \%$ galled and varied from 17 to $74 \%$ (Table 1). The family mean at each site for percent galled trees was regressed against the site means (mean of all families and check lots planted at the site, averaging 42 families and check lots per test) to estimate the slope $(b)$ and $r^{2}$ for each family. A slope of $b=1.0$ with small deviations from regression (i.e., a high $r^{2}$ ) indicates that a family has an average stability value $(b)$ and responds in direct proportion to increases in site-mean infection rates. A slope of $b>1$ indicates that a family is "unstable" and responds to increases in infection more than most families. When $b<1$, the family is more stable and does not respond to changes in infection level. When $r^{2}$ is low, the reliability of the regression is low, indicating possible interactions of families and sites. A high $r^{2}$ means that the performance of a family is predictable across sites.

The following regression of family means versus site means was used to calculate R-50 values for each family (see Table 2 in McKeand et al. 1999):

$$
\text { [1] } \quad \mathrm{R}-50_{i}=a_{i}+b_{i} 50
$$

where $\mathrm{R}-50_{i}$ is the predicted rust level of family $i$ at a site where average rust infection is $50 \%$; $a_{i}$ is the intercept for regression of family $i$ across sites; and $b_{i}$ is the slope for the regression of family $i$ across sites. This is the stability parameter of Finlay and Wilkinson (1963). 
To simulate the performance of a bulk seed lot of resistant families, test data for individuals from the six families with the most stable resistance were pooled. All six families had low R-50 values, and five of the six had $b$ significantly ( $p \leq$ 0.05) lower than 1 (McKeand et al. 1999). The sixth family (F6) with a nonsignificant but still low stability value $(b=$ 0.75) was known to be a resistant family from other trials (data from N.C. State University - Industry Cooperative Tree Improvement Program). There were two tests, sites 9 and $\mathrm{T}$, where only one or two of the resistant families were planted. These sites were dropped from the analyses of the bulk seed lot. The mean of this resistant bulk seed lot at each site was regressed against the site means, as was done for the individual open-pollinated families.

\section{Results and discussion}

As reported in McKeand et al. (1999), highly significant family differences (family mean heritability $h_{\mathrm{F}}^{2}=0.84$ ) for rust infection were found across the 28 test sites. Predicted R-50 values varied from $22.4 \%$ for the most resistant family to $75.3 \%$ for the most susceptible family. Slopes of the mean family rust percentage regressed against the mean site rust percentage did not differ significantly from $b=1.0$ ( $p \leq$ $0.05)$ for 34 of the 43 families, indicating average stability for 8 -year rust resistance for about $80 \%$ of the families. The relatively high $r^{2}$ and examination of residuals indicated that the linear models fit the data well. Interacting families contributed about $20 \%$ to the highly significant $\mathrm{G} \times \mathrm{E}$ interaction sum of squares from the analysis of variance; this was primarily due to heterogeneous regressions (McKeand et al. 1999).

Family means for infection (R-50 values) are significantly $(p \leq 0.05)$ correlated with both the stability parameters $(r=$ $0.78)$ and the intercept $(r=0.41)$ of the prediction equations. The strong relationship between stability and the family mean for a trait ( $r=0.78$ in this study) is a common finding in $\mathrm{G} \times \mathrm{E}$ trials ( $\mathrm{Li}$ and McKeand 1989; Finlay and Wilkinson 1963).

Although rust resistance for most families was predictable, the average $r^{2}$ value of 0.78 for the regression equations for predicting rust resistance was substantially lower than for the regressions predicting stem volume in the same tests, where the average $r^{2}$ value was 0.94 (McKeand et al. 1997). The relatively low $r^{2}$ values for the rust regressions suggest more important genotype by environment interactions for rust resistance than for volume growth. We speculated (McKeand et al. 1999) that for some families, the points that deviate the most from the regression line could be due to the interaction of a family's susceptibility and (or) resistance and specific rust avirulence and (or) virulence that may differ from site to site (e.g., Kuhlman et al. 1995).

Upon more detailed evaluation of the family regressions across sites, it appeared that the most resistant families were those that had the lowest $r^{2}$ for the regression. We looked at the relationships between the R-50 value, the stability parameter $b$ (the slope of the regression line when family means for $\%$ galled are regressed against the site means for $\%$ galled in McKeand et al. (1999)), and the intercept of the regressions with the predictability of rust resistance (the $r^{2}$ for the regression). The correlation between $b$ and $r^{2}$ for the 43 families in the 28 tests was 0.75 (Fig. 1). In other words,
Fig. 1. Relationship between rust stability (slope, $b$ ) and predictability $\left(r^{2}\right)$ for 43 open-pollinated families in 28 tests. The open diamonds (families F1-F6) were identified as the most resistant families in the study.

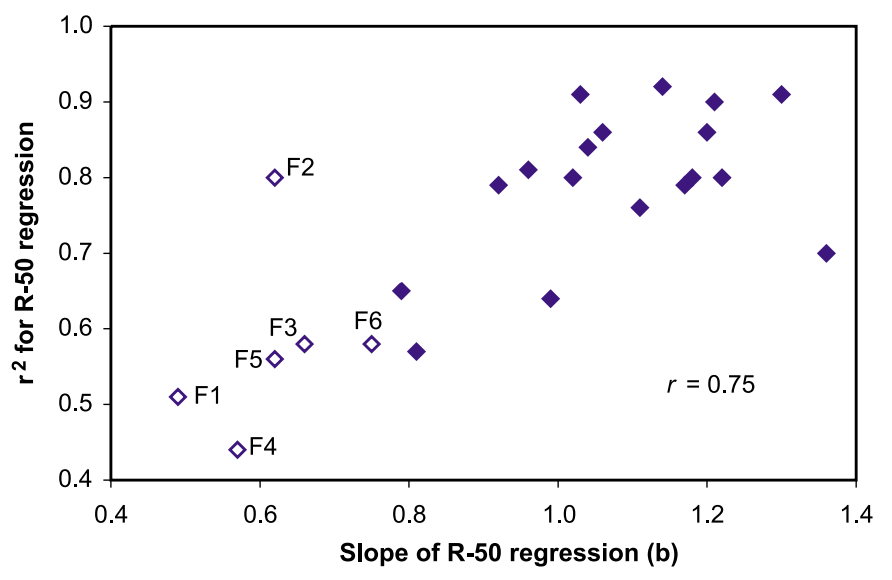

the most resistant or stable $(b<1)$ families had the poorest regressions (low $r^{2}$ values), whereas the less resistant families typically had higher $r^{2}$ values. Considering the relationship between $b$ and $r^{2}$, the predictability of the performance of the resistant families across sites is poor. As expected, families with the low R-50 values typically had low $r^{2}$ values $(r=0.56)$, but the intercepts of the prediction equations were not significantly $(p=0.14)$ correlated with predictability $(r=-0.23)$.

The average stability parameter for the six most resistant families (F1-F6) was $b=0.62$ with an average $r^{2}=0.58$; the overall mean of all 43 families was $b=1.05$ with an average $r^{2}=0.78$. It is clear from Fig. 1 that five of these six resistant families had low coefficients of determination and relatively unpredictable rust performance.

When the regressions for these six families are carefully evaluated (Fig. 2), rust infection for any of these families rarely exceeds the test mean. Foresters are still relatively well off deploying these families as opposed to families with average resistance. Nevertheless, on some sites the performance will be substantially better or worse than predicted.

It is interesting that in two of the six resistant families (F2 and F6), major gene resistance to fusiform rust has been identified (Wilcox et al. 1996; H.V. Amerson, N.C. State University, unpublished data). We speculate that the unpredictable resistance in the six families (i.e., those labeled in Fig. 1) is due to interactions of specific resistance genes in these families and corresponding avirulence and (or) virulence levels in the pathogen populations that may differ among sites. With regard to fusiform rust disease, interactions of host major genes with different pathogen genotypes (single aeciospore or single urediniospore isolates) have been common in greenhouse screening trials (Kuhlman et al. 1997; Stelzer et al. 1999; H.V. Amerson, unpublished data) and may well explain the unpredictable families in these field trials.

Although the predictability of the individual resistant families was relatively low (average $r^{2}=0.58$ for the six families), if these families were bulked into a resistant seed lot, the bulked seed lot performed in a more predictable manner (Fig. 3). The coefficient of determination for the bulk is 0.74 
Fig. 2. Regression of family means for \% rust infection versus site means for \% rust infection for the six resistant families.

Family F1

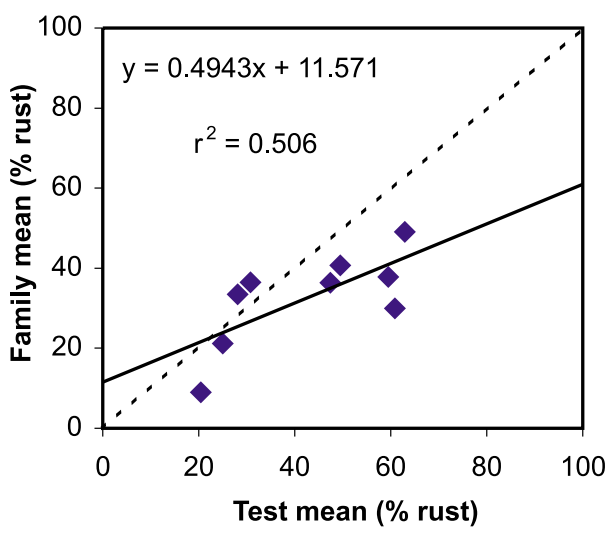

Family F3

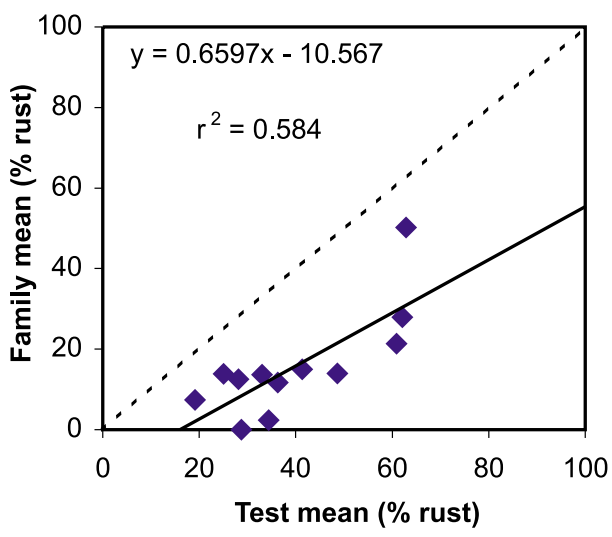

Family F5

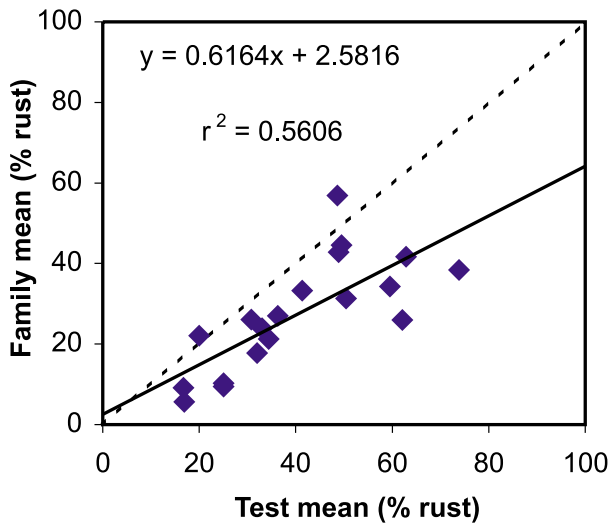

and is very similar to the average $r^{2}$ over all 43 families, which was 0.78 .

There appears to be some tests where the bulk did not do as well as most (Fig. 3). Tests in Ware County, Ga. (D); McIntosh County, Ga. (G); and Baldwin County, Ala. (H) seem to be hot spots for virulence (lack of avirulence)
Family F2

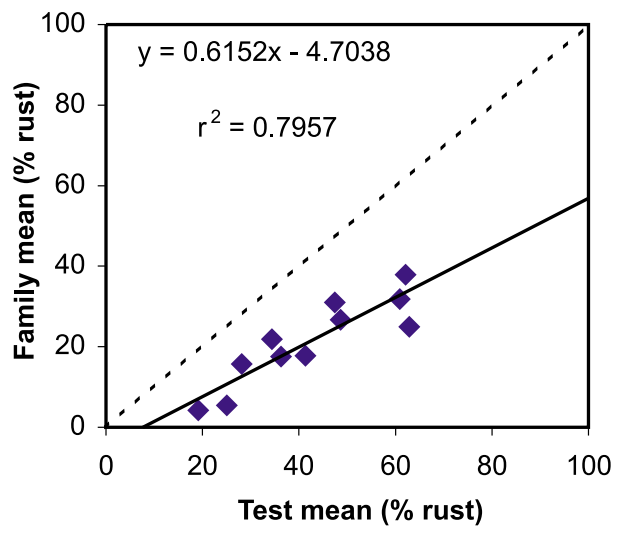

Family F4

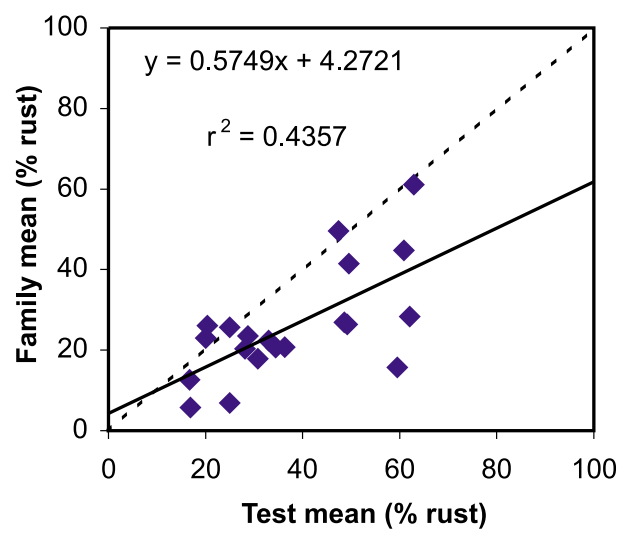

Family F6

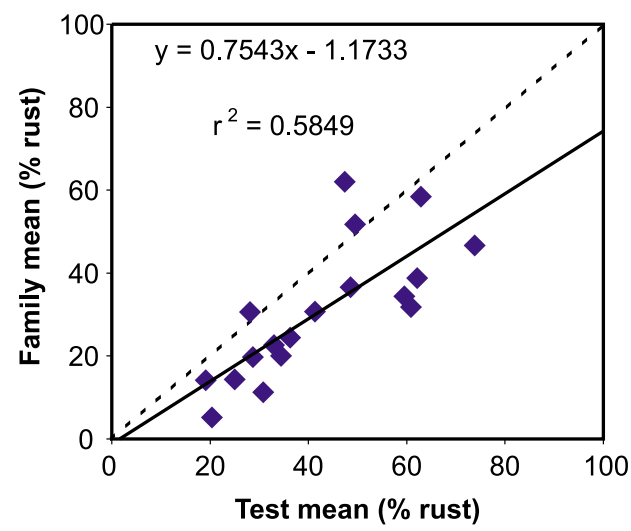

against the resistance in at least some the six selected families. At these three tests, there were four to six families making up the bulk. If these three tests were dropped from the regression analysis, the intercept is 1.56 and the slope is 0.52 (i.e., the family bulk is more resistant) with an $r^{2}=$ 0.91 ; therefore, it is very predictable on the other 23 sites. 
Fig. 3. Regression of means for $\%$ rust infection from a 6-family bulk seed lot against site means for $\%$ rust infection for all sites, with the exception of two sites ( 9 and $\mathrm{T}$ ) that had only one or two of these families. Test sites (see Table 1 for codes) in Ware County, Ga. (code D or open circle); McIntosh County, Ga. (code $\mathrm{G}$ or open triangle); and Baldwin County, Ala. (code H or open square) are identified.

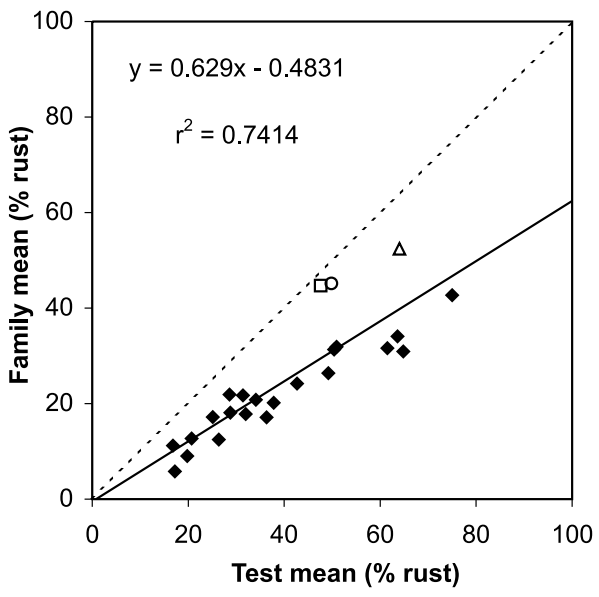

We are still confident that resistant genotypes of loblolly pine can be identified and deployed in high rust-hazard areas, but, from these analyses, it is clear that the predicted performance of the most resistant families will be less reliable than that for all the families. Bulk deployment of four to six highly resistant families appears to be a good solution to obtaining stable and predictable performance across a range of sites. In the southeastern United States, when foresters establish loblolly pine plantations in high rust-hazard zones, the practice has been to $(i)$ use seed orchard mixes from rust-resistant seed orchards or (ii) deploy individual rust-resistant families such as F1-F6 to specific sites. The seed orchard mixes typically would consist of 15 or more open-pollinated families, so the selection differential for resistance is only moderate. Still higher gain for rust resistance from seed orchard mixes can be achieved if bulk seed lots of only the top few families are deployed.

\section{Acknowledgements}

The financial and in-kind support by members of the North Carolina State University (NCSU) - Industry Cooperative Tree Improvement Program and the NCSU - Industry Rust Research Program made this study possible. The support of the NCSU Department of Forestry and the N.C. Agricultural Research Service is gratefully acknowledged. The comments from the CJFR reviewers were appreciated.

\section{References}

Anderson, R.L., McClure, J.P., Cost, N.D., and Uhler, R.J. 1986. Estimating fusiform rust losses in five southeast states. South. J. Appl. For. 10: 237-240.
Barber, J.C., Dorman, K.W., and Bauer, E. 1957. Slash pine progeny tests indicate genetic variation in resistance to rust. USDA For. Serv. Res. Note SE-104.

Eberhart, S.A., and Russell, W.A. 1966. Stability parameters for comparing varieties. Crop Sci. 6: $36-40$

Finlay, K.W., and Wilkinson, G.N. 1963. The analysis of adaptation in a plant-breeding programme. Aust. J. Agric. Res. 14: 742-754.

Jewell, F.F., and Mallett, S.L. 1967. Testing slash pine for rust resistance. For. Sci. 13: 412-418.

Kinloch, B.B., and Stonecypher, R.W. 1969. Genetic variation in susceptibility to fusiform rust in seedlings from a wild population of loblolly pine. Phytopathology, 59: 1246-1255.

Kinloch, B.B., and Walkinshaw, C.H. 1991. Resistance to fusiform rust in southern pines: How is it inherited? In Rusts of Pine. Proceedings IUFRO Rusts of Pine Working Party Conference, Can. For. Serv. North. For. Res. Cent. Inf. Rep. NOR-X-317, Edmonton, Canada. Edited by Y. Hiratsuka et al. pp. 219-228

Kuhlman, E.G. 1992. Interaction of virulent single-gall isolates of Cronartium quercuum f. sp. fusiforme and resistant families of loblolly pine. For. Sci. 38: 641-651.

Kuhlman, E.G., and Matthews, F.R. 1993. Variation in virulence among single-aeciospore isolates from single-gall isolates of $\mathrm{Cro}-$ nartium quercuum f. sp. fusiforme. Can. J. For. Res. 23: 67-71.

Kuhlman, E.G., and Powers, H.R., Jr. 1988. Resistance responses in half-sib loblolly pine progenies after inoculation with Cronartium quercuum f. sp. fusiforme. Phytopathology, 78: 484-487.

Kuhlman, E.G., Powers, H.R., Jr., and Pepper, W.D. 1995. Relative fusiform rust resistance of loblolly and slash pine sources and families in Georgia and South Carolina. U.S., For. Serv., Southeast. For. Exp. Stn. Res. Pap. SE -291.

Kuhlman, E.G., Amerson, H.V., Jordan, A.P., and Pepper, W.D. 1997. Inoculum density and expression of major gene resistance to fusiform rust disease in loblolly pine. Plant Dis. 81: 597-600.

Li, B., and McKeand, S.E. 1989. Stability of loblolly pine families in the southeastern U.S. Silvae Genet. 38: 96-101.

McKeand, S.E., Crook, R.P., and Allen, H.L. 1997. Genotypic stability effects on predicted family responses to silvicultural treatments in loblolly pine. South. J. Appl. For. 21: 84-89.

McKeand, S.E., Li, B., and Amerson, H.V. 1999. Genetic variation in fusiform rust resistance in loblolly pine across a wide geographic range. Silvae Genet. 48: 255-260.

Powers, H.R., Jr., and Kraus, J.F. 1986. A comparison of fusiform rust-resistant loblolly pine seed sources. South. J. Appl. For. 10: 230-232.

Powers, H.R., Jr., Schmidt, R.A., and Snow, G.A. 1981. Current status and management of fusiform rust on southern pines. Annu. Rev. Phytopathol. 19: 353-371.

Schmidt, R.A., Powers, H.R., Jr., and Snow, G.A. 1981. Application of genetic disease resistance for the control of fusiform rust in intensively managed southern pine. Phytopathology, 31: 993-997.

Stelzer, H.E., Doudrick, R.L., Kubisiak, T.L., and Nelson, C.D. 1999. Prescreening slash pine and Cronartium pedigrees for evaluation of complementary gene action in fusiform rust disease. Plant Dis. 83: 385-389.

Walkinshaw, C.H., and Bey, C.F. 1981. Reaction of field-resistant slash pine to selected isolates of Cronartium quercuum $\mathrm{f}$. sp. fusiforme. Phytopathology, 71: 1090-1092.

Wilcox, P.L., Amerson, H.V., Kuhlman, E.G., Liu, B.H., O’Malley, D.M., and Sederoff, R.R. 1996. Detection of a major gene for resistance to fusiform rust disease in loblolly pine by genomic mapping. Proc. Natl. Acad. Sci. U.S.A. 93: 3859-3864. 